\title{
Profil Pengelolaan dan Ketersediaan Obat Anti Diabetes Oral di Puskesmas
}

\author{
Abdul Rahem* \\ Fakultas Farmasi, Universitas Airlangga, Surabaya \\ *Corresponding author: abdulrahem@ff.unair.ac.id
}

\begin{abstract}
Background: The availability of medicine at Primary Healthcare Center (puskesmas) is vital in ensuring rational use of medicine and improving public trust towards health services provided by puskesmas. Proper management of medicine is therefore required to ensure the procured medicine will be able to met the need of puskesmas in Kabupaten Pamekasan. Objective: To identify the profile the management and availability of oral antiabetic drugs at puskesmas. Methods: A descriptive observational study design using questionnaire was conducted at 11 puskesmas in Pamekasan to address this objective. Results: Overall, puskesmas adopted consumption pattern for procurement to determine the type and amount of medicine with additional procurement can be requested through local Healthcare Office when the medicine is about to run out. Seventy two percent of puskesmas were not in accordance to the standard for storage affecting only $23.3 \%$ of medicines were categorized as safe to use. Conclusion: In conclusion, puskesmas in Pamekasan has not met standard for storage and safety use category is reached $23 \%$ only.
\end{abstract}

Keywords: management, primary healthcare center, medicine availability

\begin{abstract}
Abstrak
Pendahuluan: Ketersediaan obat di puskesmas merupakan aspek yang sangat penting dalam menjamin kerasionalan penggunaan obat oleh pasien, dan membangun kepercayaan masyarakat terhadap fasilitas pelayanan kesehatan tersebut. Pengelolaan obat di puskesmas haruslah baik dan benar, karena pengelolaan yang baik dan benar akan menjamin ketersediaan obat sesuai dengan kebutuhan puskesmas. Tujuan: Untuk mengetahui profil pengelolaan dan ketersediaan obat antidiabetes oral pada Puskesmas di Kabupaten Pamekasan. Metode: Desain penelitian deskriptif observasional, metode pengumpulan data dilakukan dengan menggunakan kuesioner sebagai instrumen. Penelitian ini dilakukan pada 11 puskesmas di Kabupaten Pamekasan. Hasil: Semua puskesmas melakukan perencanaan pada awal tahun dengan menggunakan pola konsumsi sebagai pertimbangan menentukan jenis dan jumlah kebutuhan obatnya. Pengadaan kepada Dinas Kesehatan dilakukan pada saat obat akan habis atau sesuai kebutuhan. Penyimpanan obat di puskesmas $72,72 \%$ tidak sesuai dengan standar yang berlaku, ketersediaan obat antidiabetes oral dengan kategori aman hanya 23,3\%. Kesimpulan: Pengelolaan obat pada 11 puskesmas di Kabupaten Pamekasan belum sesuai dengan standar, dan ketersediaan obat dengan kategori aman hanya $23,3 \%$.
\end{abstract}

Kata kunci: pengelolaan, ketersediaan obat, puskesmas

\section{PENDAHULUAN}

Obat merupakan bagian mata rantai antara pasien dan pelayanan kesehatan, sehingga obat tidak dapat dipisahkan dari fasilitas pelayanan kesehatan (faskes). Obat dapat menyelamatkan jiwa dan dapat meningkatkan kesehatan masyarakat. Ketersediaan obat pada setiap fasilitas pelayanan kesehatan, merupakan faktor yang sangat penting dalam meningkatkan kerasionalan penggunaan obat oleh pasien dan mendorong kepercayaan pasien terhadap fasilitas pelayanan kesehatan tersebut (Quick dkk., 1997). Ketersediaan obat di puskesmas menjadi kritis mengingat puskesmas merupakan faskes yang paling dekat dengan masyarakat dan paling banyak dikunjungi oleh masyarakat. Di setiap kecamatan minimal ada 1 (satu) puskesmas. Selain itu kadang juga dilengkapi dengan puskesmas pembantu di beberapa desa.

Ketersediaan obat dan bahan medis habis pakai di puskesmas, tergantung pada pengelolaan dari obat tersebut. Pengelolaan obat dan bahan medis habis pakai 
merupakan salah satu kegiatan pelayanan kefarmasian, yang dimulai dari perencanaan, permintaan, penerimaan, penyimpanan, pendistribusian, pengendalian, pencatatan dan pelaporan serta pemantauan dan evaluasi. Tujuannya adalah untuk kelangsungan ketersediaan dan keterjangkauan obat dan bahan medis habis pakai yang efisien, efektif dan rasional. Penelitian (Salwati, 2016), menunjukkan bahwa beberapa puskesmas di Kabupaten dibeberapa puskesmas Kabupaten Barito Kuala Kalimantan Selatan mengalami kekosongan obat, sementara yang lain banyak ditemukan stok obat berlebih dan stok mati. Jika pengelolaan obat dan bahan medis habis pakai dilakukan dengan benar, sesuai dengan standar yang ada, maka kekosongan atau kelebihan obat dapat dikurangi, sehingga obat akan selalu cukup atau stok aman sesuai kebutuhan.

Keberhasilan pengelolaan obat dipengaruhi oleh beberapa faktor antara lain: latar belakang pendidikan, pelatihan pengelolaan obat yang diikuti, kepatuhan terhadap standar yang ada, pengalaman mengelola obat dari pengelola obat tersebut. Pertimbangan perencanaan dalam menentukan jenis dan jumlah obat yang sering disebut kuantifikasi kebutuhan, dan sumber mendapatkan obat juga berpengaruh terhadap keberhasilan pengelolaan obat.

Dari uraian di atas, ingin dilakukan penelitian dengan tujuan untuk mengetahui profil pengelolaan dan ketersediaan obat di puskesmas Kabupaten Pamekasan. Obat antidiabetes oral yang ada di puskesmas Kabupaten Pamekasan dipilih sebagai model karena prevalensi penderita diabetes di Pamekasan cukup tinggi yaitu pada tahun 2016 sebanyak 1742 penderita (Meidikayanti \& Wahyuni, 2017). Selain itu, obat antidiabetes oral digunakan pada jangka waktu yang lama. Diabetes yang tidak terkontrol akan berisiko terjadinya komplikasi kronis seperti mikrovaskular dan neuropati (Ralineba dkk., 2015). Salah satu cara untuk pengendalian diabetes melitus adalah patuh dalam menggunakan obat secara rasional dan teratur seumur hidup. Penggunaan obat secara rasional tergantung dari ketersediaan obatnya.

Dari latar belakang di atas dapat dirumuskan masalah penelitian sebagai berikut: Bagaimanakah profil pengelolaan obat antidiabetes di puskesmas Kabupaten Pamekasan?; Bagaimanakah profil ketersediaan obat antidiabetes di Puskesmas Kabupaten Pamekasan?

\section{METODE PENELITIAN}

Desain penelitian observasional, yang bersifat deskriptif. Penelitian ini bertempat di puskesmas yang ada di Kabupaten Pamekasan, yang diambil 11 (sebelas) puskesmas sebagai sampel. Sebagai sumber informasi (responden) penelitian adalah penangunggjawab pengelolaan obat pada masingmasing puskesmas tersebut. Pengambilan data dilakukan dengan observasi pada penyimpanan obat dan dokumen, serta dengan kuesioner pada penanggungjawab pengelolaan obat. Pengelolaan yang diteliti dalam penelitian ini adalah meliputi: Perencanaan, Pengadaan, dan Penyimpanan.

Observasi tentang Perencanaan dalam penelitian ini meliputi: waktu perencanaan, pertimbangan dalam menentukan jenis dan jumlah obat yang akan diadakan (kuantifikasi), dan keberadaan pedoman atau standar prosedur operasional (SPO) dalam melakukan perencanaan. Selain itu karakteristik pengelola seperti latar belakang pendidikan, pelatihan yang terkait dengan pengelolaan obat yang pernah diikuti oleh penanggungjawab pengelolaan obat tersebut juga akan diamati dalam penelitian ini.

Aspek Pengadaan yang diteliti adalah waktu pengadaan, sumber pengadaan, metode pengadaan. Aspek Penyimpanan yang menjadi fokus pada penelitian ini antara lain; penataan obat, kesesuaian dengan suhu, pemisahan antara obat rusak atau kadaluarsa dengan obat yang lain.

Selain pengelolaan, variabel lainnya adalah ketesediaan obat di puskesmas. Ketersediaan terdiri dari stok berlebih, aman, kurang dan kosong.

\section{HASIL DAN PEMBAHASAN}

\section{Karakteristik responden}

Latar belakang pendidikan penangungjawab pengelolaan obat di puskesmas mayoritas adalah perawat sebesar 45,4\%, untuk tenaga teknis kefarmasian (TTK) hanya $27,3 \%$ sebagaimana tercantum pada Tabel 1.

Berdasarkan informasi dari petugas di Dinas Kesehatan, pada saat dilakukan penelitian, hanya ada satu puskesmas yang sudah memiliki Apoteker walaupun masa kerja kurang lebih satu tahun. Puskesmas tersebut bukan termasuk dalam sampel penelitian ini. 
Pada Tabel 1, lulusan SMK Farmasi tidak dimasukkan sebagai tenaga kesehatan berdasarkan Undang Undang nomor 36 tahun 2014 tentang tenaga kesehatan. Standar kualifikasi untuk tenaga kesehatan minimal memiliki latar belakang pendidikan diploma 3 (D3). Sehingga bila ditinjau dari sudut ketenagaan, kondisi ini tidak memenuhi syarat sebagai penanggungjawab atau tidak layak, baik yang berasal dari SMK Farmasi maupun tenaga lainnya. Keadaan ini tidak sesuai dengan peraturan perundang-undangan yang berlaku.

Dalam Peraturan Pemerintah nomor 51 tahun 2009 tentang pekerjaan kefarmasian pasal 20 disebutkan bahwa dalam menjalankan pekerjaan kefarmasian pada fasilitas pelayanan kefarmasian, apoteker dapat dibantu oleh apoteker pendamping dan/atau tenaga teknis kefarmasian. Artinya yang dapat melakukan pekerjaan kefarmasian hanya apoteker yang dapat dibantu TTK. Undang-undang nomor 36 tahun 2009 tentang Kesehatan, pada pasal 108 dinyatakan bahwa praktik kefarmasian harus dilakukan oleh tenaga kesehatan yang memiliki keahlian dan kewenangan sesuai dengan peraturan perundangan. Pada pasal tersebut sudah dilakukan yudisial review dan diputuskan oleh Mahkamah konstitusi bahwa yang dimaksud tenaga kesehatan yang memiliki keahlian dan kewenangan tersebut adalah tenaga kefarmasian, yaitu apoteker yang dapat dibantu oleh TTK.

Tabel 1. Latar belakang pendidikan penangungjawab pengelolaan obat di Puskesmas

\begin{tabular}{llcc}
\hline No. & $\begin{array}{l}\text { Tingkat Pendidikan } \\
\text { pengelola obat }\end{array}$ & $\mathrm{n}$ & $\%$ \\
\hline 1. & SMK Farmasi & 3 & 27,3 \\
2. & S1 Keperawatan & 5 & 45,4 \\
3. & D3 Kebidanan & 2 & 18,2 \\
4. & SMA & 1 & 9,1 \\
\hline Jumlah & 11 & 100 \\
\hline No. & Pengalaman pengelola obat & $\mathrm{n}$ & $\%$ \\
& pada pelatihan kefarmasian & & \\
\hline 1. & Tidak Pernah & 11 & 100 \\
2. & Pernah & 0 & 0 \\
\hline Jumlah & 11 & 100 \\
\hline
\end{tabular}

Seluruh penanggungjawab pengelolaan obat belum pernah mengikuti pelatihan yang terkait dengan pengelolaan obat, sebagaimana tercantum pada Tabel 1. Pelatihan sangat penting untuk meningkatkan kemampuan sumberdaya manusia dalam melakukan pengelolaan obat, mengingat sumberdaya manusia sangat berpengaruh terhadap ketepatan dalam pengelolaan (Sanjaya \& Hidayat, 2016). Peraturan Menteri Kesehatan nomor 74 tahun 2016 tentang standar pelayanan kefarmasian di puskesmas, menyebutkan bahwa tenaga kefarmasian yang ada di puskesmas harus selalu meningkatkan pengetahuan, keterampilan dan perilaku dalam rangka menjaga dan meningkatkan kompetensinya. Upaya peningkatan kompetensi tenaga kefarmasian dapat dilakukan melalui pengembangan profesional berkelanjutan melalui proses pendidikan dan pelatihan. Pendidikan dan pelatihan adalah salah suatu proses atau upaya peningkatan pengetahuan dan keterampilan di bidang kefarmasian atau bidang yang berkaitan dengan kefarmasian secara berkesinambungan untuk mengembangkan potensi dan produktivitas tenaga kefarmasian secara optimal.

\section{Perencanaan}

Waktu perencanaan obat, berdasarkan data pada Tabel 2, semua responden melakukan pada awal tahun atau di akhir bulan tahun sebelumnya. Kebiasaan mereka melakukan perencanaan hanya satu kali, dan diusulkan ke Dinas kesehatan, kemudian dilakukan permintaan melalui Laporan Pemakaian dan Lembar Permintaan Obat (LPLPO) setiap obat habis, dengan demikian tidak sama setiap tahunnya dalam melakukan permintaan. Perencanaan yang hanya dilakukan sekali dalam setahun (awal tahun) memiliki risiko kekosongan obat, karena pola penyakit dan penggunaan obat oleh penderita dari waktu ke waktu senantiasa mengalami perubahan. Selain itu fleksibilitas atau pengadaan yang dilakukan sewaktuwaktu akan berpengaruh terhadap ketersediaan obat yang baik (Sanjaya \& Hidayat, 2016). Berdasarkan hasil pengamatan pada semua puskesmas, dan informasi dari petugas, didapatkan informasi bahwa belum ada puskesmas yang menggunakan software atau memanfaatan teknologi informasi, sehingga untuk pengambilan keputusan dalam perencanaan tidak bisa cepat dan akurat. Padahal pengambilan keputusan yang cepat merupakan hal yang penting dalam suatu organisasi. Salah satu komponen yang dapat mendukung adalah sistem informasi (Larasati dkk., 2013).

Menurut Quick dkk. (1997), dalam menentukan jenis dan jumlah obat yang dibutuhkan atau kuantifikasi kebutuhan obat, ada beberapa hal yang dijadikan pertimbangan yaitu dengan penggunaan obat periode sebelumnya yang dikenal dengan pola konsumsi, dan didasarkan pola penyakit yang biasa dikenal dengan pola epidemiologi. Masing-masing pola memiliki kelebihan dan kelemahan. Jika menggunakan pola penyakit saja ada kesulitan mengestimasi, karena prevalensi penyakit senantiasa mengalami pergeseran dari waktu ke waktu. Kalau menggunakan pola 
konsumsi saja, maka sangat mungkin jika penggunaan obat periode sebelumnya tidak rasional, akan terus menjadi tidak rasional. Yang sangat ideal dalam kuantifikasi kebutuhan obat adalah mengkombinasikan pola konsumsi dan pola penyakit.

Tabel 2. Data waktu perencanaan obat

\begin{tabular}{llcc}
\hline No. & Waktu perencanaan & $\mathrm{n}$ & $\%$ \\
\hline 1. & Awal tahun & 11 & 100 \\
2. & Tiga bulanan & 0 & 0 \\
\hline Jumlah & 11 & 100 \\
\hline No. & $\begin{array}{l}\text { Dasar kuantifikasi } \\
\text { perencanaan obat }\end{array}$ & $\mathrm{n}$ & $\%$ \\
\hline 1. & Pola penyakit & 0 & 0 \\
2. $\quad$ Konsumsi & 11 & 100 \\
3. $\quad$ Pola penyakit + konsumsi & 0 & 0 \\
\hline Ju.mlah & 11 & 100 \\
\hline No. & Keberadaan SPO pengelolaan & $\mathrm{n}$ & $\%$ \\
& obat di Puskesmas & & \\
\hline 1. & Ada & 0 & 0 \\
2. & Tidak ada & 11 & 100 \\
\hline Jumlah & 11 & 100 \\
\hline
\end{tabular}

Pada penelitian ini sebagaimana Tabel 2, responden $100 \%$ hanya menggunakan pertimbangan pola konsumsi. Setelah dilakukan pengamatan secara langsung terhadap LPLPO, ternyata mereka tidak benar dalam menggunakan data pola konsumsi. Kadangkala mereka tidak melihat data penggunaan obat yang ada, hanya memperkirakan sesuai estimasi dan kebiasaan mereka merencanakan. Sebagai contoh dari salah satu puskesmas, glibenclamide tablet $5 \mathrm{mg}$, awal tahun 2016 merencanakan kebutuhan untuk tahun 2016 sebanyak 1000 tablet, ternyata penggunaan sepanjang tahun 2016 sebanyak 1.540 tablet, sehingga di akhir tahun tidak ada sisa stok. Ini termasuk kategori stok kosong pada puskesmas tersebut, padahal di Dinas Kesehatan belum tentu obat tersebut tidak ada. Contoh di puskesmas lain, glibenclamide tablet $5 \mathrm{mg}$, stok awal 1.700 tablet, permintaan 2000 tablet, pemakaian hanya 330 tablet, sehingga di akhir tahun masih tersisa 3.370 tablet, yang berarti stok berlebih. Ini menunjukkan bahwa sebenarnya perencanaan yang dilakukan oleh petugas pengelolaan obat di puskesmas tersebut tidak mengacu pada pola konsumsi dan juga bukan pola penyakit.

Standar prosedur operasional (SPO) dalam melakukan pengelolaan obat di semua fasilitas pelayanan kesehatan termasuk di puskesmas, sangat diperlukan untuk memandu pengelola supaya senantiasa sesuai dengan standar yang telah ditentukan, menjaga kualitas dan keamanan obat (Kemenkes RI, 2016). Pada penelitian ini sebagaimana disajikan pada Tabel 2, didapatkan tidak seorangpun pengelola obat di puskesmas yang memiliki SPO. Pada pasal 4 Permenkes no 74 tahun 2016 tentang standar pelayanan kefarmasian di puskesmas disebutkan bahwa: penyelenggaraan standar pelayanan kefarmasian di puskesmas harus didukung oleh ketersediaan sumber daya kefarmasian, pengorganisasian yang berorientasi kepada keselamatan pasien, dan standar prosedur operasional sesuai dengan ketentuan peraturan perundang-undangan. Keharusan penggunaan SPO di fasilitas pelayanan kefarmasian juga disebutkan pada pasal 23 Peraturan Pemerintah no 51 tahun 2009 tentang pekerjaan kefarmasian yaitu: dalam melakukan pekerjaan kefarmasian, Apoteker harus menetapkan SPO, yang harus dibuat secara tertulis dan diperbaharui secara terus menerus sesuai perkembangan ilmu pengetahuan dan teknologi di bidang farmasi dan ketentuan peraturan perundang-undangan. Dengan demikian puskesmas tersebut belum menjalankan standar pelayanan kefarmasian sesuai peraturan yang berlaku.

\section{Pengadaan}

Sumber mendapatkan obat $100 \%$ masih berasal dari Dinas Kesehatan sebagaimana data pada Tabel 3. Di era Jaminan Kesehatan Nasional (JKN), sebenarnya ada dana Kapitasi yang bisa digunakan untuk pembelian obat secara langsung oleh puskesmas. Sebagaimana diatur pada pasal 3 dalam peraturan Menteri Kesehatan Republik Indonesia nomor 21 tahun 2016 (Kemenkes RI, 2016), bahwa dana kapitasi yang diterima oleh fasilitas pelayanan kesehatan tingkat pertama dari Badan Penyelenggara Jaminan Sosial (BPJS) kesehatan, dimanfaatkan seluruhnya untuk pembayaran jasa pelayanan kesehatan dan dukungan biaya operasional pelayanan kesehatan. Dukungan biaya operasional pelayanan kesehatan sebagaimana dimaksud dimanfaatkan untuk biaya obat, alat kesehatan, dan bahan medis habis pakai serta biaya operasional pelayanan kesehatan lainnya. Jadi seharusnya dana kapitasi sebagian untuk jasa dan sebagian untuk obat. Hal ini tidak bisa dilakukan oleh pihak puskesmas karena belum ada apoteker sebagai syarat untuk bisa melakukan pengadaan obat secara langsung. Waktu pengadaan dilakukan pada saat obat habis atau hampir habis, biasanya setiap 3 bulan. Metode pengadaan biasanya melalui tender terbuka, tender tebatas dan pembelian langsung. Karena sumbernya hanya dari dinas kesehatan kabupaten, maka pengadaannya dengan metode permintaan melalui LPLPO kepada Dinas Kesehatan Kabupaten Pamekasan. 
Tabel 3. Data pengadaan obat

\begin{tabular}{llcc}
\hline No. & Sumber mendapatkan obat & $\mathrm{n}$ & $\%$ \\
\hline 1. & Dinas Kesehatan & 11 & 100 \\
\hline $2 . \quad$ Sumber lain & 0 & 0 \\
\hline Jumlah & 11 & 100 \\
\hline No. & Waktu pengadaan atau permintaan & $\mathrm{n}$ & $\%$ \\
\hline $1 . \quad$ Setelah obat kosong & 11 & 100 \\
\hline $2 . \quad$ Berkala & 0 & 0 \\
\hline Jumlah & 11 & 100 \\
\hline No. & $\begin{array}{l}\text { Metode pengadaan permintaan } \\
\text { obat }\end{array}$ & $\mathrm{n}$ & $\%$ \\
\hline $\begin{array}{l}\text { Permintaan langsung melalui } \\
\text { LPLPO }\end{array}$ & 11 & 100 \\
\hline Pembelian langsung atau lainnya & 0 & 0 \\
\hline Jumlah & 11 & 100 \\
\hline
\end{tabular}

\section{Penyimpanan}

Untuk mempertahankan kualitas obat selama penyimpanan, diperlukan standar penyimpanan secara benar. Tujuan penyimpanan agar mutu obat yang tersedia di puskesmas dapat dipertahankan sesuai dengan persyaratan yang ditetapkan. Menurut Permenkes no 74 tahun 2016, penyimpanan obat harus mempertimbangkan beberapa hal berikut: bentuk dan jenis sediaan; kondisi yang dipersyaratkan dalam penandaan di kemasan obat, seperti suhu penyimpanan, cahaya, dan kelembaban; mudah atau tidaknya meledak/terbakar; narkotika dan psikotropika disimpan sesuai dengan ketentuan peraturan perundangan; tempat penyimpanan tidak dipergunakan untuk penyimpanan barang lainnya yang menyebabkan kontaminasi.

Dari data penelitian pada Tabel 4, menunjukkan bahwa hanya $18,28 \%$ puskesmas yang sesuai secara keseluruhan dengan standar penyimpanan atau baik, yang lain tidak sesuai dengan ketentuan yang ada dalam Permenkes tersebut. Penyimpanan obat pada beberapa puskesmas tidak dipisahkan menurut jenis sediaan yang menggunakan prinsip kombinasi first In first out (FIFO) dan first expired first out (FEFO). Penyimpanan obat pada ruang logistik farmasi masih terdapat beberapa obat yang tidak disertai label nama obat, Berdasarkan Permenkes No. 74 Tahun 2016 bahwa komponen yang harus diperhatikan dalam penyimpanan obat antara lain obat dan bahan kimia yang digunakan diberi label yang secara jelas memuat nama, tanggal kadaluarsa dan peringatan khusus. Salah satu tujuan pengaturan penyimpanan obat yang baik agar obat-obat dapat diperoleh dengan mudah tanpa terjadi kesalahan pengambilan oleh petugas (Siregar, 2004).
Tabel 4. Data penyimpanan obat

\begin{tabular}{llcc}
\hline No. & Penyimpanan obat sesuai suhu & $\mathrm{n}$ & $\%$ \\
\hline 1. & Sesuai & 2 & 18,28 \\
2. & Tidak sesuai & 8 & 72,72 \\
\hline Jumlah & & 11 & 100 \\
\hline No. & Penyimpanan obat fifo & $\mathrm{N}$ & $\%$ \\
\hline 1. & Sesuai & 2 & 18,28 \\
2. & Tidak sesuai & 8 & 72,72 \\
\hline Jumlah & & 11 & 100 \\
\hline No. & Penataan obat rusak & $\mathrm{N}$ & $\%$ \\
\hline 1. & Dipisah & 3 & 27,3 \\
2. & Tidak dipisah & 8 & 72,7 \\
\hline Jumlah & & 11 & 100 \\
\hline
\end{tabular}

Hal lain yang ditemukan adalah obat yang sama tidak disimpan dalam tempat sama, tetapi disimpan di bangunan lain yang terpisah. Banyak puskesmas yang tidak dilengkapi dengan pengendalian suhu ruangan seperti AC. Kondisi ruang penyimpanan obat merupakan hal yang kritis dan penting diperhatikan karena terdapat banyak obat yang mudah rusak jika kena panas, sehingga sangat penting untuk memantau suhu ruangan (Kagashe \& Massawe, 2012). Masih banyak ditemukan obat yang disimpan di atas meja administrasi. Obat yang sudah kadaluarsa dan obat rusak belum dipisah dari obat lainya sebagaimana Tabel 4 sebanyak 72,7\%. Pada hal seharusnya sudah dipisah atau dimusnahkan sesuai dengan peraturan perundangan yang berlaku.

\section{Ketersediaan obat}

Ketersediaan obat antidiabetes oral (OAD) yang disajikan pada Tabel 5, menunjukkan bahwa mayoritas tergolong kategore stok obat berlebih yaitu $36,3 \%$. Untuk puskesmas yang tergolong ketersediaan obatnya kosong dan kurang jumlahnya sama masingmasing 18,2\%, sementara untuk kategori stok obat aman hanya $27,3 \%$. Kondisi ini kurng baik mengingat OAD merupakan obat yang sangat dibutuhkan, karena pengobatan diabetes melitus harus dilakukan seumur hidup. Seharusnya ketersediaan obat memenuhi keriteria aman untuk kebutuhan puskesmas (Salwati, 2016). Ketidaksesuaian ketersediaan obat dipengaruhi oleh beberapa faktor antara lain perencanaan yang kurang mendekati kebutuhan riil, pola penyakit yang berubah di wilayah puskesmas tersebut (Silvania dkk., 2012), keterlambatan waktu pengambilan ke dinas kesehatan setempat atau keterlambatan pengiriman dari puskesmas (Carolien dkk., 2017). 
Tabel 5. Data ketersediaan obat antidiabetes oral

\begin{tabular}{llcc}
\hline No. & Ketersediaan obat & $\mathrm{N}$ & $\%$ \\
\hline 1. & Berlebih & 4 & 36,3 \\
2. & Aman & 3 & 27,3 \\
3. & Kurang & 2 & 18,2 \\
4. & Kosong & 2 & 18,2 \\
\hline \multicolumn{2}{l}{ Jumlah } & 11 & 100 \\
\hline
\end{tabular}

\section{KESIMPULAN}

Profil pengelolaan: waktu perencanaan obat dilakukan hanya satu kali yaitu di awal tahun; pertimbangan kuantifikasi menggunakan pola konsumsi yang tidak sesuai; belum ada puskesmas yang memiliki SPO; permintaan obat pada Dinas kesehatan dilakukan setiap obat habis/akan habis dengan jumlah sesuai dengan yang direncanakan pada awal tahun; Sumber mendapatkan obat $100 \%$ dari dinas kesehatan kabupaten; Penyimpanan obat mayoritas tidak sesuai dengan standar yang berlaku; yaitu 72,72\%; Profil ketersediaan obat antidiabetes oral dengan kategori aman hanya 23,3\%.

\section{REFERENSI}

Carolien, I., Fudholi, A. \& Endarti, D. (2017). Evaluasi Ketersediaan Obat Sebelum dan Sesudah Implementasi JKN pada Puskesmas di Kabupaten Keerom Provinsi Papua. Jurnal Manajemen dan Pelayanan Farmasi; 7; 30-39.

Kagashe, G. A. B. \& Massawe, T. (2012). Medicine Stock Out and Inventory Management Problems in Public Hospital in Tanazia: A Case of DAR E SALAAM Region Hospitals. International Journal of Pharmacy; 2; 252-259.

Kementerian Kesehatan Republik Indonesia (Kemenkes RI). (2016). Peraturan Menteri kesehatan Republik Indonesia nomor 21 tahun 2016 tentang penggunaan dana kapitasi jaminan kesehatan Nasional untuk jasa pelayanan kesehatan dan dukungan biaya operasional pada fasilitas kesehatan tingkat pertama milik pemerintah Daerah. Jakarta: Kementerian Kesehatan Republik Indonesia.

Kementerian Kesehatan Republik Indonesia (Kemenkes RI). (2016). Peraturan Menteri Kesehatan Republik Indonesia Nomor 74 Tahun 2016 tentang standar Pelayanan Kefarmasian di Puskesmas. Jakarta: Kementerian Kesehatan Republik Indonesia.
Larasati, I., Susilo, H. \& Riyadi. (2013). Analisis Sistem Informasi Manajemen Persediaan Obat. Jurnal Administrasi Bisnis; 1; 57 - 67.

Meidikayanti, W. \& Wahyuni, C. U. (2017). Hubungan Dukungan Keluarga dengan Kualitas Hidup Diabetes Melitus Tipe 2 di Puskesmas Pademawu. Jurnal Berkala Epidemiologi; 5; 240-252.

Presiden Republik Indonesia. (2009). Peraturan Pemerintah Nomor 51 Tahun 2009 Tentang Pekerjaan Kefarmasian. Jakarta: Presiden Republik Indonesia.

Presiden Republik Indonesia. (2014) Undang-undang Nomor 36 Tahun 2014 Tentang Tenaga Kesehatan. Jakarta: Presiden Republik Indonesia.

Presiden Republik Indonesia. (2009). Undang-undang Nomor 36 Tahun 2009 Tentang Kesehatan. Jakarta: Presiden Republik Indonesia.

Quick, J., Rankin, J., Laing, R., O'Connor, R., Hogerzeil, H. \& Dukes, M. (1997). Managing Drug Supply, $2^{\text {nd }}$ Edition, Revised and Expanded, $2^{\text {nd }}$ ed. USA: Kumarin Press.

Ralineba, T., Netshikweta, M. L. \& Shilubane, N. H. (2015). Knowledge and Practices Associated with Diabetes among Patients with Chronic Diabetes Mellitus in Rural Areas of Vhembe District, Limpopo Province, South Africa. Journal of Human Ecology; 51; 193-201

Salwati. (2016). Analisis Hubungan Profil Ketersediaan Obat terhadap Profil Rasionalitas Peresepan pada Pasien Rawat Jalan di Puskesmas Kabupaten Barito Kuala Provinsi Kalimantan Selatan. Tesis; Fakultas Farmasi Universitas Surabaya, Surabaya.

Sanjaya, G. Y. \& Hidayat, A. H. (2016). Pemantauan Obat dan Perbekalan Kesehatan di Indonesia: Tantangan dan Pengembangannya. Jurnal Manajemen dan Pelayanan Farmasi; 6; 169168.

Silvania, A., Hakim, L. \& Satibi. (2012). Evaluasi Kesesuaian antara Perencanaan dan Realisasi Penerimaan Obat di Puskesmas Rawat Inap SeKabupaten Sleman Tahun 2008-2010. Jurnal Manajemen dan Pelayanan Farmasi; 2; 90-94.

Siregar, C. J. P. (2004). Farmasi Rumah Sakit Teori dan Terapan. Jakarta: EGC. 